Geomatics, Landmanagement and Landscape No. 3 • 2018, 35-44

\title{
ISSUE OF QUALITY AND RELIABILITY OF SPATIAL RECORDS INFORMATION IN THE CONTEXT OF DATA CONCERNING BOUNDARY POINTS
}

\author{
Szczepan Budkowski, Urszula Litwin
}

\begin{abstract}
Summary
Records of land and buildings, in accordance with the regulations that remain in force within Poland, act as a real estate cadastre. As a public register, they must fulfil certain specific functions and tasks expected of them. The aim of the present work is to analyse land records data, as illustrated with selected examples, as well as to assess and verify the suitability of these materials in the scope of the functions performed by the real estate cadastre, and in the context of possible legislative changes. Literature studies and the analysis of sample cadastral surveys make it possible to draw conclusions regarding the proposed changes.
\end{abstract}

\section{Keywords}

real estate cadastre $\bullet$ quality of spatial data

\section{Introduction}

A real estate cadastre is a public register containing data on all land plots, buildings and premises. As a public register of a universal nature, it contains technical data and subject-specific descriptive data. Due to the nature of the data collected, the Act on Geodetic and Cartographic Law [Ustawa], in Article 21, lists specific goals that this particular register should implement. The objectives are related to spatial planning, determination of the tax and benefits dimension, keeping public statistics, property labelling in land and mortgage registers, proper real estate management [Litwin and Zawora 2009], as well as keeping the records of agricultural holdings. For the tasks thus defined, it is clear that the real estate cadastre performs many important functions, which include:

- A registration function consisting in the establishment, maintenance and constant updating of a homogeneous, country-wide, and ordered system, containing data on the land, buildings and premises, as well as their rightful owners and users. The registration function is closely related to the information function [Felcenloben 2009]; 
- The information function is a direct result of the recording of descriptive information and numerical data concerning the land, buildings, and premises, and their rightful owners. It consists in providing data to entities having a legal interest therein, on request, and upon payment, in the form of extracts, excerpts, and copies of maps (Article 24a item 3) [Felcenloben 2009];

- The control function results from the specific format of the register, which the real estate cadastre is. Namely, the entry in the register is not only a notification, but due to the fact that the entries appearing in the cadastre have a precisely defined legal effect, the registration authority is obliged to control and verify the submitted geodetic and cartographic documentation [Felcenloben 2009];

- The tax function, in the historical context, is the most important function of the cadastre, which is one of the reasons for determining the extent of rights to property. This function is associated with the need to charge property tax (for land, buildings, or premises). It is also worth noting that the lack of a general property taxation is the reason for the limitations of this function. The cadastre thus performs an indirect, intermediate function, because on the basis of this very register, the competent tax authority (the head of the municipality, the mayor or the president) determines the amount of tax due [Felcenloben 2009];

- The law-making function is connected with the possibility of including the cadastral survey in geodetic and cartographic resources, on the basis of which an entry is made of constitutive importance. The law-making function is revealed in a particular way at the moment of disclosing data on land, buildings or premises in the land and mortgage registers. At the same time, it is worth noting that under the current provisions of law, the warranty does not cover the designation of real estate. Therefore, the boundaries, area and location are not covered by legal protection. According to the author of this publication, in this regard, we should follow the example and experience of Austria [Gesamte... 1955-2018], whereby the established boundaries, which have been confirmed by the signatures of the parties, should be covered by a warranty [Felcenloben 2009];

- The protective function consists in ensuring the credibility and reliability of the relationship between the actual state of and on the land, and the legal status shown in the land and mortgage registers. The protective function is the implication of the law-making function, thanks to the written rights (warranty) and information by providing access to data (guarantee of transparency) [Felcenloben 2009];

- The integration function is closely related to the way the registry is constructed in technical terms [Felcenloben 2011]. Ensuring uniformity may be expressed, among others, by: providing a uniform system of spatial references, a uniform system of measures, uniformity of applied standards for disclosing and preparing data for the register, or building an integrated IT system [Felcenloben 2009]. 


\section{Issues under examination}

The abovementioned and briefly characterized functions performed by real estate cadastre are connected with the necessity of the real estate register to provide the registration data of the appropriate quality, which is manifested by the determination of the extent of rightful ownership or usufruct of the given land. This is reinforced by the definition of a land plot included in the Regulation by the Minister of Regional Development and Construction of March 29, 2001 regarding land and buildings records [Rozporządzenie 2001]: "The plot of land is a continuous extent of land, located within one area, homogeneous in legal terms, and separated from its surroundings by means of boundary lines." While performing geodetic works on registration boundaries, it is necessary to address the attributes of boundary points (Table 1), and subject them to analysis, that would allow, inter alia, for the following [Ustawa]:

- conducting of demarcation proceedings, in accordance with the provisions of the Act on Geodetic and Cartographic Law [Ustawa],

- analysis and removal of discrepancies in the course of boundaries, associated with possible boundary overlaps,

- appropriate classification of boundary points, in order to reinstate or indicate the boundary marks [Rozporządzenie 2001],

- carry out the determination and establishment of boundaries, under the provisions of the regulation regarding the land and buildings records [Rozporządzenie 2001].

When comparing the data resulting from the two regulations, it is worth noting the fact of harmonizing the database, and achieving the situation of eliminating possible clashes or overlaps between the markings [Konieczna 2013]. It is also extremely important that discrepancies in the method of marking boundary points will result in a lack of data interoperability and harmonization, which in turn will affect the reliability of data, and will cause serious errors [Hanus et al. 2018]. The necessity of building a reliable database in the context of two-dimensional plots is essential for the implementation of the assumptions for contemporary, state-of-the-art 3D cadastre [Karabin 2013]. The analysis of the credibility of boundaries is important not only in the aspect of rightful ownership, but also in the context of spatial planning [Litwin and Szewczyk 2012].

In this author's opinion, treating the problem of defining boundaries in the mode of the Regulation on land and building records of 2015 [Rozporządzenie 2001] on the same level as the delimitation defined by the Geodetic and Cartographic Law Act [Ustawa] as "ZRD-1" is an oversight as well as, unfortunately, an obvious mistake. Another argument supporting this thesis is that there is no separate ZRD attribute for the boundaries of plots adopted in accordance with the procedure described in the Regulation [Rozporządzenie 2013]. Detailed studies on the mode of conducted subdivision proceedings were carried out and presented by the author in his Master's thesis [Budkowski 2015]. Therefore, in this author's opinion, it is not possible to treat this activity on a par with the establishment of boundaries using ZRD-1. 
Critical comments can also be made in the context of code 7, which is "Screen-based vectorisation of the cadastral raster map with the simultaneous application of geodetic results from field measurements (linear measures)" This attribute causes inaccuracy in determining the "base" point, which would be the anchor point for linear measurements.

Table 1. Itemized information on the source of data for boundary points

\begin{tabular}{|c|c|c|}
\hline $\begin{array}{l}\text { Value } \\
\text { of the } \\
\text { attribute }\end{array}$ & $\begin{array}{l}\text { Source of data (ZRD) } \\
\text { until } 31 \text { December } 2013 \\
\text { Regulation } 2001\end{array}$ & $\begin{array}{l}\text { Source of data (ZRD) } \\
\text { at present } \\
\text { Regulation } 2015\end{array}$ \\
\hline 1 & $\begin{array}{l}\text { Geodetic field measurements } \\
\text { preceded by the determination of } \\
\text { boundaries }\end{array}$ & $\begin{array}{l}\text { Geodetic field measurements preceded by the } \\
\text { delimitation of real estate boundaries, reinstating the } \\
\text { boundary marks, or determining their location using } \\
\text { another procedure }\end{array}$ \\
\hline 2 & $\begin{array}{l}\text { Geodetic field measurements not } \\
\text { preceded by the determination of } \\
\text { boundaries }\end{array}$ & $\begin{array}{l}\text { Geodetic field measurements not preceded by the } \\
\text { delimitation of real estate, reinstating the boundary } \\
\text { marks, or determining their location using another } \\
\text { procedure }\end{array}$ \\
\hline 3 & $\begin{array}{l}\text { Photogrammetric measurements } \\
\text { preceded by the determination } \\
\text { of the boundaries and their } \\
\text { indication }\end{array}$ & $\begin{array}{l}\text { Photogrammetric measurements preceded by the } \\
\text { determination of the boundaries of land registration } \\
\text { plots and their indication, or photogrammetric } \\
\text { measurements of unambiguously identified boundary } \\
\text { points, previously established in the form provided } \\
\text { for by legal regulations }\end{array}$ \\
\hline 4 & $\begin{array}{l}\text { Photogrammetric measurements } \\
\text { not preceded by the } \\
\text { determination of the boundaries } \\
\text { and their indication }\end{array}$ & $\begin{array}{l}\text { Photogrammetric measurements not preceded by the } \\
\text { determination of the boundaries of land registration } \\
\text { plots and their indication }\end{array}$ \\
\hline 5 & $\begin{array}{l}\text { Approved projects of real estate } \\
\text { division }\end{array}$ & $\begin{array}{l}\text { Approved projects of real estate division or real estate } \\
\text { consolidation and division }\end{array}$ \\
\hline 6 & Land consolidation & Approved projects of land consolidation or exchange \\
\hline 7 & $\begin{array}{l}\text { Digitalization of the cadastral } \\
\text { map or automatic vectorisation } \\
\text { of the raster map with the } \\
\text { simultaneous application of } \\
\text { geodetic results from field } \\
\text { measurements }\end{array}$ & $\begin{array}{l}\text { Screen-based vectorisation of the cadastral raster } \\
\text { map with the simultaneous application of geodetic } \\
\text { results from field measurements (linear measures) }\end{array}$ \\
\hline 8 & Other & $\begin{array}{l}\text { Screen-based vectorisation of the cadastral raster } \\
\text { map without the simultaneous application of geodetic } \\
\text { results from field measurements }\end{array}$ \\
\hline 9 & - & $\begin{array}{l}\text { Screen-based vectorisation of cartographic materials } \\
\text { other than the cadastral raster map }\end{array}$ \\
\hline
\end{tabular}

Source: developed by the author based on the regulation by the Minister of Regional Development and Construction of March 29, 2001 on the land and building records, and the Regulation by the Minister of Administration and Digitization of November 29, 2013 amending the ordinance on land and buildings records (Dz. U. 2013 item 1551) 


\section{Research results}

The author's empirical experience also points to the fact that there are correlations between the attribute of the source point for obtaining the ZRD information about the position of the given point, and the BPP point location error, related to the historical measurement methods and those currently used today [Wytyczne... 1984]. This is also impacted by technological progress, and consequently by the measuring tapes being replaced by rangefinders or GPS receivers. Nevertheless, experience related to geodetic execution seems to confirm the fact that surveyors adopt values from the tables attached to the cadastral surveys, without conducting proper case analysis.

Accuracy characteristics from different time periods affect the quality of existing registration data. The accuracy of determining the location of points differed over the years [Latoś 1998]. The error of the geodetic network has the greatest impact on the error of determining the details of the terrain. Also having a large impact on possible inaccuracies, and sometimes even causing glaring errors, is the failure to update the databases, as exemplified in Figure 1. The limits of land use (marked in pink) do not coincide with the boundaries of plots (marked in black).

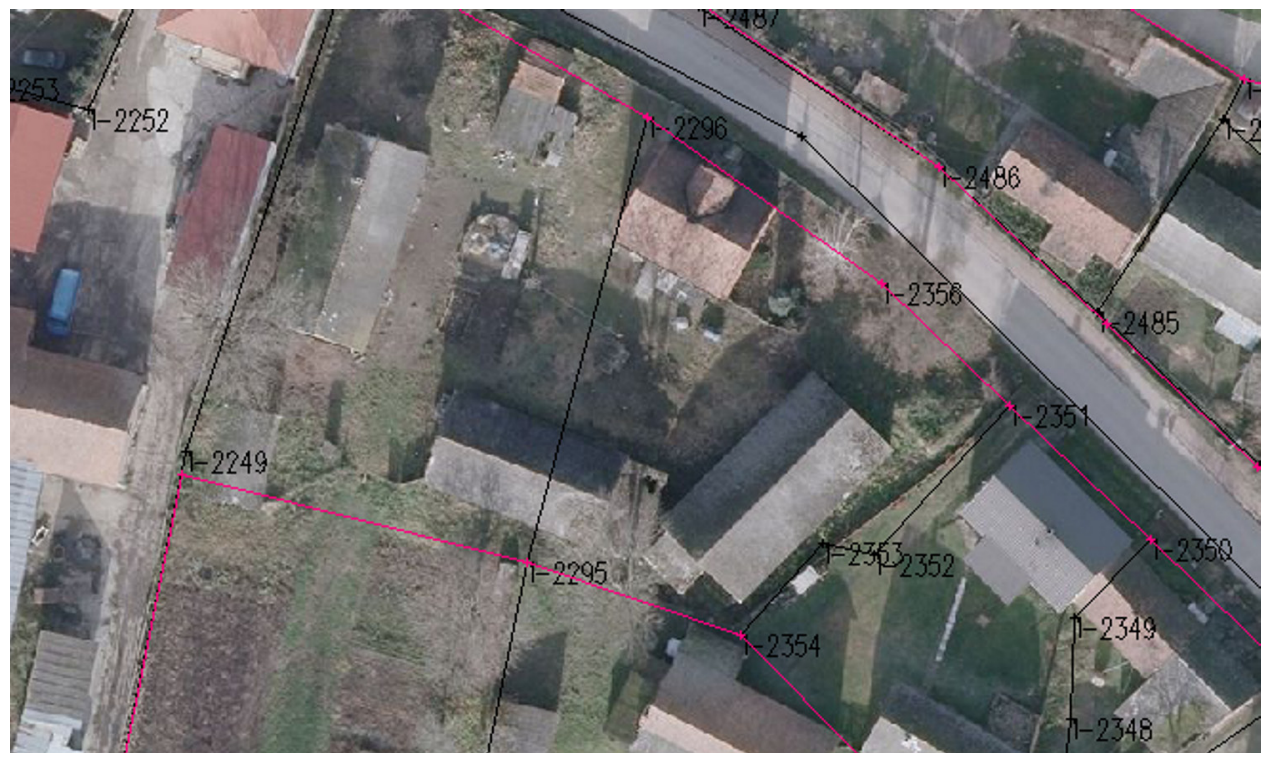

Source: data of the Pińczów district authorities

Fig. 1. Fragment of a vector cadastral map on the orthophotomap foundation before the modernization: Pińczów town, in the area of Pełczyska

The situations presented herein are often the result of many years of neglect and mistakes. It is not hard to guess that errors in the designation of individual points are 
then translated into errors in the designation of the area sizes of land plots. Undoubtedly, this state of affairs is influenced by the technical guidelines, which tolerate lower accuracy of determination of points due to other measurement technologies (classical plane surveying, blueprints, orthogonal survey method). Examples can be found in legal surveys, which constitute the source for the existing registration data. In Figure 2a, the course of the boundary line determined by the parties is shown with the points to which the relative measures are given. Having analysed the whole of the survey, the author noticed the lack of coordinates of reference points in any arrangement whatsoever.

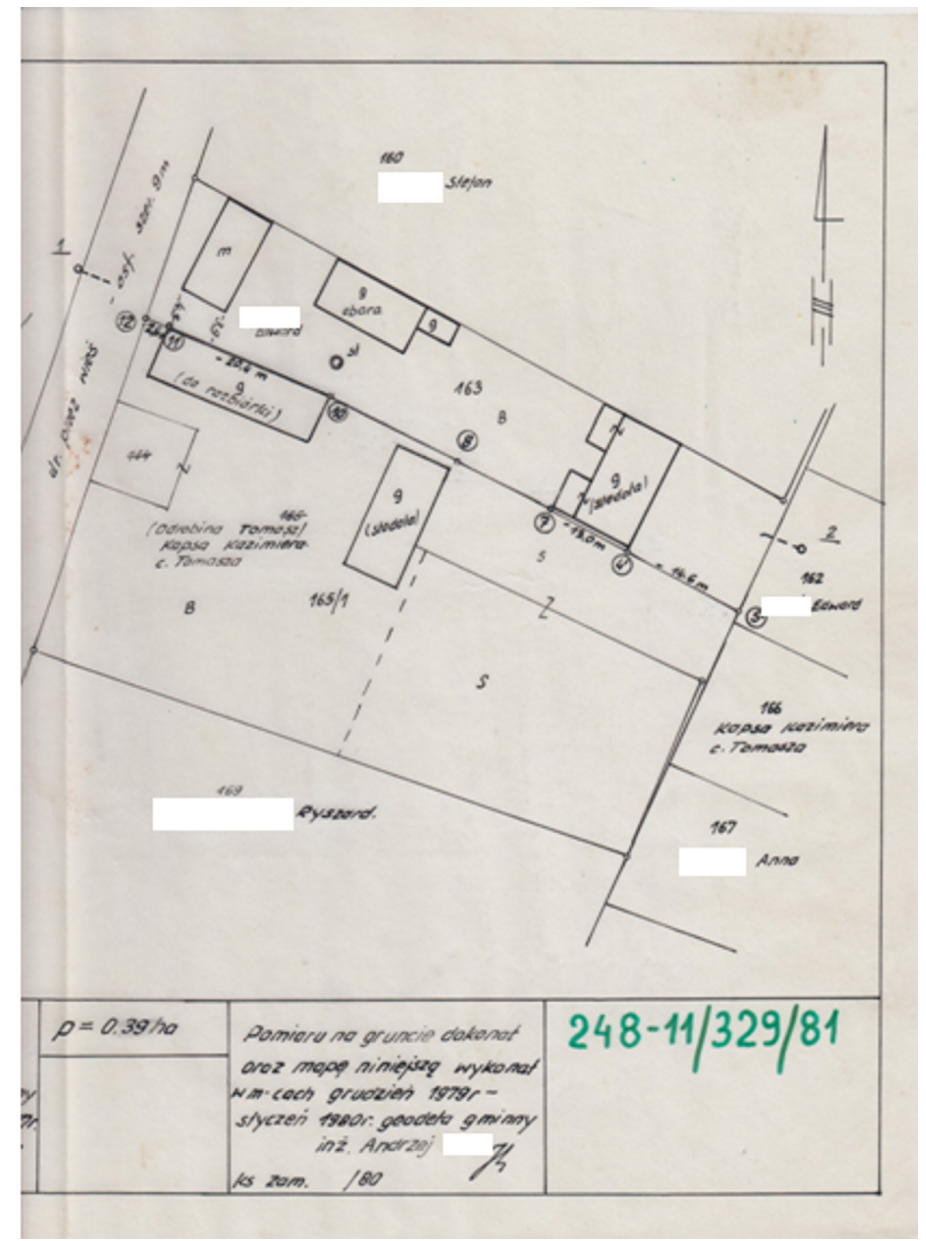

Source: demarcation survey 248-11/329/81, Pińczów district authorities

Fig. 2a. Measurement sketch from demarcation survey in Pińczów Biskupice, 1981

Such situation may result in the inability to use the survey in part, in the absence of other data regarding buildings and plots, or a significantly changed situation in the 
field, as well as the loss of one of the objects (intended for demolition), whose corners also signal the course of the plot's boundaries. The fact that the areas of plots were provided with an accuracy of down to 0.01 ha is also significant, which has an impact on the lower than currently used accuracy of determining the cadastral area.

When analysing legal surveys (Fig. $2 \mathrm{~b}$ ), it is also worth mentioning the commonly applied practice when performing property divisions in the scope of determining the area of plots created in this way. The said practice consisted in measuring the area of the newly separated plot of land, and subtracting it from the area size of the plot registered before the division. From the measurement sketches of survey number 3104-74/1964, it is clear that the measurement covered newly-created plots, while the area of one plot was inferred by subtracting the area of the plot of land from the total size before the division of the plots (certified by handwritten calculations noted alongside the sketch). No wonder that this way of keeping records may currently raise justified doubts, in view of the quality of cadastral data.

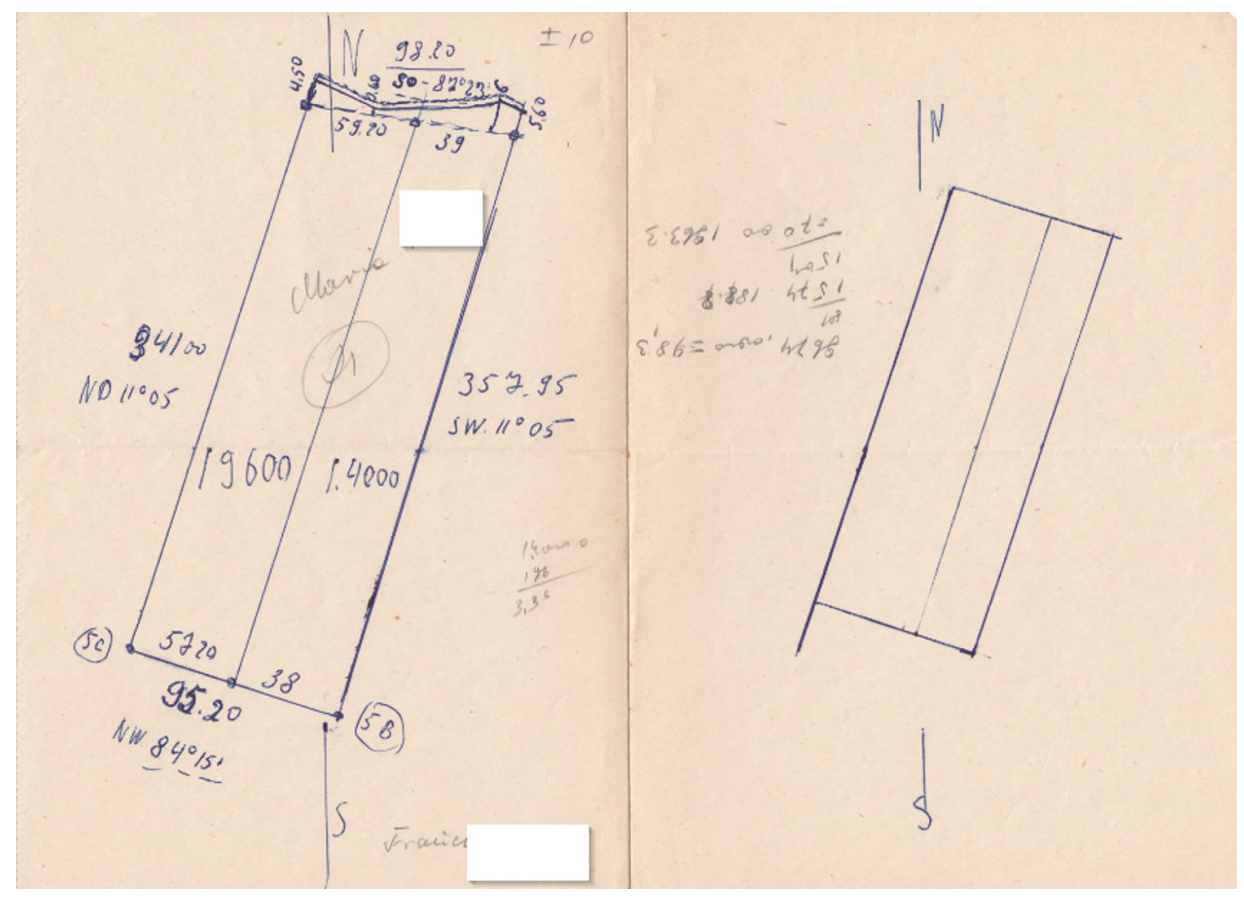

Source: Pińczów district authorities

Fig. 2b. Sketch of the survey no. 3104-74 / 1964 for division of plot number 26

In both examples of the surveys, the author analysed the STB (stabilization) attribute of the boundary points. The 1981 survey report does not contain such information, while the 1964 division report protocol informs us about the stabilization of points using the boundary markers. The author's experience in the scope of the conducted 
work clearly indicates that while the information about the stabilization usually appears in accordance with the actual status, the type of material used for stabilization tends to be simply omitted. This applies in particular to the mark used as the sub-centre. In this case, the author is of the opinion that either the existing attribute should be changed, or a new one should be added, in order to specify the type of stabilization as well as to numerically define, according to the numerus clausus principle, the attribute values; being for marks on the surface:

- 1 - boundary stone,

- 2 - steel pipe,

- 3 - metal mandrel,

- 4 - wooden pole,

- 5 - buoy,

- 6 - other.

And for marks under the surface:

- 1 - bottle,

- 2 -stone,

- 3 - steel tube manual,

- 4 - other.

When analysing the cases originating in Pińczów, where work is currently being carried out in the framework of the second phase of the ZSIN project, we can notice inconsistencies in the boundaries of the land plots in the context of land use visible on the orthophotomap with a 10-centimetre field pixel (Fig. 3). In addition, measurements were made using the GNSS receiver, which allowed us to confirm the above.

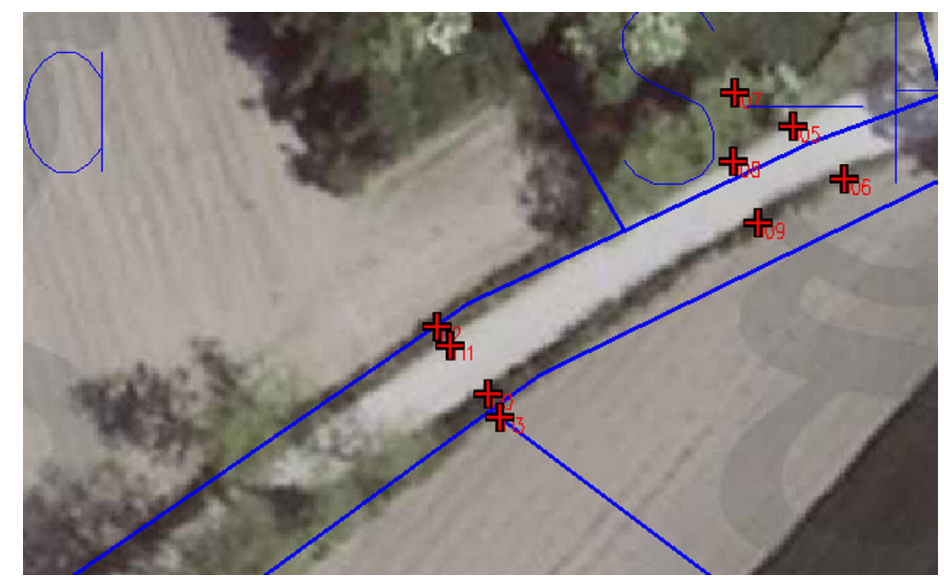

Source: own study

Fig. 3. An example of inconsistency of registered land plots with results of measurements from a GNSS receiver 


\section{Summing up}

Based on the analysis of legal surveys, it should be stated that contractors very often take data from the surveys at face value, without critical judgement, assuming the values given in the BPP column to be correct. This leads to discrepancies (a point with a small error value in the survey can be adopted, although its actual field coordinates are different). In this author's opinion, the development of measurement technologies, as well as legislative changes in this respect, should entail the necessity to convert the value of the location error, so that the data becomes more reliable.

\section{Conclusions}

1. Over the years, apart from technical guidelines regulating the accuracy of measurements taken, also the measurement technologies have changed, and thus the error of the location of boundary points has changed. It can therefore be concluded that there are correlations between the position error of the point and the measurement technology, which are caused not only by legislative changes, but above all by the development of technology in the field of measuring instruments used, for instance replacement of measuring tapes by total stations.

2. Another conclusion that arises is the relationship between the source of obtaining information about the location of points, and its location error. This is influenced by the quality of the geodetic and cartographic documentation, as well as the time period in which the documentation was created. Also impacting the error of the location of points will be the measurement technologies applied in the given time period, as well as technical guidelines that can be expressed in a different way of marking the ZRD attribute, which the author has demonstrated in Table 1.

3. The analysis of the attached surveys, as well as the professional practice of the author, leaves no illusions about the necessity of introducing changes to the attribute boundary points. It is the author's considered opinion that these changes should include the unification of the value of the ZRD attribute, and the introduction of a new value of the attribute discussed earlier in this paper. Conversion of points within the BPP attribute is necessary, so that legislative changes do not affect the limited credibility of determining the value of this particular attribute. In the author's opinion, it is also necessary to introduce changes in the scope of the STB attribute.

4. An extremely important aspect is the obvious necessity for the evolution of registers being kept, which leads us to the conclusion about the need to unify the records in the context of development works aimed at the introduction of a multi-dimensional cadastre. 


\section{References}

Budkowski S. 2015. Analiza postępowań podziałowych prowadzonych na obszarze gminy Słomniki, praca magisterska.

Felcenloben D. 2009. Kataster nieruchomości rejestrem publicznym. Wydawnictwo Gall, Katowice.

Felcenloben D. 2011. Criteria for assessing the quality of data and information collected and shared from the real estate cadastre. Przegląd Geodezyjny, 1, 11-17.

Gesamte Rechtsvorschrift fur allgemeines Grungbuchsgesetz, 1955-2018.

Hanus P., Pęska-Siwik A., Szewczyk R. 2018. Spatial analysis of the accuracy of the cadastral parcel boundaries. Computers and Electronics in Agriculture, 144, 9-15, January.

Karabin M. 2013. Koncepcja modelowego ujęcia katastru 3D w Polsce. Prace Naukowe Politechniki Warszawskiej. Geodezja, 51.

Konieczna J. 2013. Znaczenie jakości danych katastralnych w pracach realizowanych na obszarach wiejskich. Infrastruktura i Ekologia Terenów Wiejskich, 3(III).

Latoś S. 1998. Analiza dokładności map numerycznych i cyfrowych. Geodezja, AGH, 4, 2, $163-177$.

Litwin U., Szewczyk R. 2012. Morfologia działek przyczynkiem kształtowania krajobrazu. Infrastruktura i Ekologia Terenów Wiejskich, 2.

Litwin U., Zawora P. 2009. Wartościowanie struktur przestrzennych za pomocą znormalizowanych wskaźników istotności terenu. Acta Sci. Pol. Administratio Locorum, 8/2, 15-27.

Rozporządzenie Rady Ministrów z dnia 7 grudnia 2004 r. w sprawie sposobu i trybu dokonywania podziałów nieruchomości (Dz. U. z 2004 r. Nr 268, poz. 2663).

Rozporządzenie Ministra Administracji i Cyfryzacji z dnia 29 listopada 2013 r. zmieniające rozporządzenie w sprawie ewidencji gruntów i budynków (Dz. U. z 2013 r., poz. 1551).

Rozporządzenie Ministra Rozwoju Regionalnego i Budownictwa z dnia 29 marca 2001 r. w sprawie ewidencji gruntów i budynków (Dz. U. z 2001 r. Nr 38, poz. 454).

Ustawa Prawo geodezyjne i kartograficzne (tekst jedn., Dz. U. z 2017 r., poz. 2101).

Wytyczne Techniczne G-1.9. 1984. Katalog znaków geodezyjnych oraz zasad stabilizacji punków, Warszawa.

\section{Cadastral surveys}

Operat 248-11/329/81 rozgraniczeniowy Pińczów Biskupice 1981 [source: Starostwo Powiatowe Pińczów].

Operat 3104-74/1964 podziałowy Pińczów Biskupice 1964 [source: Starostwo Powiatowe Pińczów].

Prof. dr hab. inż. Urszula Litwin

Uniwersytet Rolniczy w Krakowie

Katedra Geodezji Rolnej, Katastru i Fotogrametrii

30-198 Kraków, ul. Balicka 253a

Mgr inż. Szczepan Budkowski

GEO-Mapa Szczepan Budkowski

37-450 Stalowa Wola, ul. Staszica 15b/19

e-mail: szbudkowski@o2.pl 